\title{
Non-participatie in de doe-democratie
}

\author{
Gideon Broekhuizen \& Ank Michels
}

\author{
Serie 'Lokale democratie doorgelicht' \\ Onder redactie van: Bas Denters \& Marcel Boogers
}

\begin{abstract}
Onderzoek naar burgerinitiatieven focust veelal op diegenen die al participeren. In dit artikel staat centraal hoe degenen die nog niet participeren, kunnen worden gemotiveerd om deel te nemen aan burgerinitiatieven. Om dit te onderzoeken gebruiken we vignetten waarin vier kernmotieven voor deelname aan burgerinitiatieven worden gekoppeld aan drie typen burgerinitiatieven. De resultaten van dit onderzoek laten zien dat mensen eerder geneigd zullen zijn om deel te nemen aan een initiatief als een beroep wordt gedaan op altruïsme. Ook blijkt dat het voor kleinschaligere, meer toegepaste burgerinitiatieven in het algemeen gemakkelijker is om mensen te motiveren. Non-participanten zullen, zeker bij de aanwezigheid van een specifiek lokaal probleem en wanneer ze gevraagd worden, eerder geneigd zijn om positief te reageren op een uitnodiging om deel te nemen. Voor meer abstracte burgerinitiatieven, zoals een burgertop waarbij niet één specifiek probleem wordt benoemd, is het veel lastiger om meer mensen te motiveren om deel te nemen.
\end{abstract}

\section{Inleiding}

De Nederlandse participatiesamenleving is volop in ontwikkeling. Overal zien we op lokaal niveau burgerinitiatieven ontstaan, al dan niet gestimuleerd door bezuinigingen van de overheid. Over het algemeen is er veel optimisme over deze vorm van burgerparticipatie, zowel bij de overheid als bij burgers zelf (Tonkens e.a., 2015; Rob, 2012). De gedachte is steeds dat niet alles aan de overheid hoeft te worden overgelaten, maar dat burgers zelf heel goed in staat zijn om problemen in hun omgeving aan te pakken. Tegelijkertijd weten we uit onderzoek naar burgerparticipatie dat maar weinig mensen veel participeren en dat veel mensen weinig participeren (Rob, 2004; WRR, 2012; Boogaard \& Michels, 2016).

Ook bij burgerinitiatieven zien we dat veel mensen niet participeren. Tonkens e.a. (2015) onderscheiden drie typen niet-actieve burgers. De afzijdige burger is van deze drie de meest structurele non-participant. Afzijdige burgers willen de politiek zo veel mogelijk aan de politiek laten en zitten ook niet te wachten op extra zorgtaken of andere taken in de buurt. De loyale burger is wel bereid om mee te denken in de richting van een participatiesamenleving, maar ziet uiteindelijk toch een hoofdrol weggelegd voor de traditionele instituties van de representatieve 
democratie. Tot slot staat de positief-kritische burger positief tegenover zowel de representatieve democratie als de participatieve democratie. Dit type burger is in de meeste gevallen bereid om zelf te participeren in bepaalde initiatieven, maar heeft simpelweg die stap nog niet gezet (Tonkens e.a., 2015: 84-97).

Het onderzoek naar non-participatie is nog grotendeels een blinde vlek. We weten dat bepaalde groepen ondervertegenwoordigd zijn (Boogaard \& Michels, 2016; Hurenkamp e.a., 2006) en dat mensen die niet participeren heel verschillende visies kunnen hebben op de participatieve en representatieve democratie (Tonkens e.a., 2015). Maar we weten niet wat mensen die niet participeren, zou motiveren om wel te participeren. In dit artikel willen we deze vraag beantwoorden met behulp van vignetten, waarin verschillende vormen van burgerinitiatieven aan respondenten worden voorgelegd. Steeds is de vraag wat hen zou motiveren om aan een dergelijk initiatief deel te nemen. De opbouw van het artikel is als volgt. We beginnen met de bespreking van vier mogelijke motieven om deel te nemen aan een burgerinitiatief. Vervolgens leggen we uit hoe het onderzoek met behulp van vignetten is vormgegeven. $\mathrm{Na}$ een bespreking van de bevindingen gaan we in op de implicaties hiervan voor initiators en organisatoren van burgerinitiatieven.

\section{Burgerinitiatieven en motieven voor deelname}

Nederland heeft een lange traditie van cocreatie van beleid, van polderen, en van andere vormen van consensusgerichte beleidsvorming (Edelenbos, 2000; De Graaf, 2007). De inbreng van burgers in beleidsvorming en -implementatie is evenmin nieuw. Dit bestond in beperkte mate al vanaf de jaren zestig (Lenos e.a., 2006), en verschillende vormen van interactieve beleidsvorming hebben zich sindsdien ontwikkeld (Pröpper, 2009). Maar lange tijd was de overheid de meest bepalende en belangrijkste partij. Burgerinitiatieven onderscheiden zich van de oude vormen van burgerparticipatie doordat veel meer wordt uitgegaan van de eigen kracht van burgers. Het uitgangspunt is dat mensen heel goed zelf, of met behulp van hun eigen sociale netwerk, in staat zijn om voor veel problemen in hun omgeving een oplossing te vinden, en dat pas in tweede instantie gekeken wordt waar aanvullende overheidssteun noodzakelijk is.

Onder burgerinitiatieven verstaan wij in dit artikel lokale initiatieven van burgers, en dus niet van ambtenaren of politici. Ten tweede is van belang dat het initiatief in zekere zin een duurzaam 'publiek goed' voortbrengt. Met andere woorden: het initiatief moet bijdragen aan publiek 'beleid' of betrekking hebben op een publieke taak die voorheen (deels) werd uitgevoerd door de overheid. Het creëren van gedeelde verantwoordelijkheid tussen burgers en overheid is het uitgangspunt van wat tegenwoordig wel de doe-democratie genoemd wordt (Van de Wijdeven, 2012). Dit sluit nauw aan bij het in het Verenigd Koninkrijk ontwikkelde concept van Big Society (Kisby, 2010). Een grotere rol voor burgers in hun eigen leefomgeving draagt eraan bij dat burgers meer betrokken zijn bij elkaar en bij hun omgeving, en daarmee ook aan een maatschappij die hechter en sterker is 
dan eerst. In de meest ideale vorm van de doe-democratie is de rol van de overheid meer een faciliterende, die draait om empowerment en het laten van ruimte aan burgers (Hendriks \& Van de Wijdeven, 2014).

Onderzoek naar bestaande burgerinitiatieven in Nederland leert dat er een grote verscheidenheid aan initiatieven bestaat. Deze verscheidenheid komt voor een groot deel doordat de meeste burgerinitiatieven duidelijk lokaal gericht zijn (Boutellier, 2011). De initiatieven hebben betrekking op problemen die zich voordoen in de directe omgeving. Daardoor zijn burgerinitiatieven in veel gevallen onvergelijkbaar met andere initiatieven, ook initiatieven in buurgemeenten.

De grote verscheidenheid in initiatieven is op twee dimensies te karakteriseren. Allereerst is er de schaal waarop een initiatief functioneert. Sommige initiatieven zijn zeer kleinschalig van opzet, en richten zich op het ondersteunen van twee of drie hulpbehoevenden in de buurt. Andere initiatieven worden op een veel grotere schaal georganiseerd, bijvoorbeeld om een wijkcentrum op te zetten voor alle wijkbewoners. Een tweede manier waarop initiatieven van elkaar verschillen, is in het soort handeling dat ze van deelnemers vragen. Initiatieven als een burgertop, die een discussieplatform voor burgers willen opzetten, zijn voornamelijk politiek van aard, en draaien vooral om overleggen. Dit soort initiatieven kunnen het beste worden omschreven als deliberatief. Andere initiatieven vragen juist voornamelijk om specifieke handelingen, zoals in het geval van het onderhouden van een dorpszwembad (Ham \& Van der Meer, 2015). Dit soort initiatieven zijn meer toegepast.

Onderzoek naar burgerinitiatieven laat zien dat deelnemers een iets meer gevarieerde achtergrond hebben dan bij andere vormen van participatie. Met name vrouwen zijn beter vertegenwoordigd (Verhoeven \& Tonkens, 2011). Desondanks is het slechts een kleine groep die deelneemt (Drosterij \& Peeters, 2011). Zo nam aan de in Nederland in 2014 en 2015 georganiseerde G1000's, een burgertop, van de mensen die waren ingeloot en uitgenodigd slechts $5 \%$ ook werkelijk deel (Boogaard \& Michels, 2016).

Dat veel burgers niet willen participeren, is op zichzelf niet nieuw. Ook in de politieke participatietheorie is een belangrijke aanname dat sommigen simpelweg niet bereid zijn om deel te nemen aan een bepaald participatieproces, om wat voor reden dan ook (Verba e.a., 1995). Een interessantere vraag is waarom mensen die welwillend staan tegenover een actievere rol, zoals de positief-kritische burger, die welwillende houding nog niet hebben omgezet in actieve deelname. Het Civic Voluntarism Model van Verba e.a. (1995) onderscheidt barrières die een drempel opwerpen om te participeren, en motieven die juist maken dat mensen wel deelnemen. De belangrijkste barrières zijn gebrek aan tijd of geld, waardoor mensen niet kunnen deelnemen. Deze drempels zijn vaak lastig weg te nemen. Het Civic Voluntarism Model onderscheidt daarnaast een aantal motieven om wel deel te nemen. De belangrijkste zijn gevraagd worden en specifieke redenen die betrekking hebben op dat ene initiatief. 
Nederlands onderzoek naar burgerinitiatieven onderstreept dat mensen een motief moeten hebben om überhaupt na te denken over deelname aan een burgerinitiatief (Denters e.a., 2013). Om in termen van drempels te blijven: waar bepaalde eigenschappen (zoals weinig tijd of geld) een drempel kunnen opwerpen om aan een initiatief deel te nemen, kunnen motieven ertoe leiden dat mensen alsnog over die drempels worden geholpen. En zelfs als geen noemenswaardige drempels kunnen worden aangewezen, is participatie niet de logische uitkomst als er geen sprake is van een duidelijk motief om ergens aan mee te doen.

Zoals eerder gezegd, is er weinig onderzoek naar degenen die niet participeren. Onderzoek naar participatie richt zich vooral op degenen die wel participeren. Onderzoek naar participatie bij burgerinitiatieven laat zien dat er verschillende motieven zijn waarom mensen besluiten om zich aan te sluiten bij een burgerinitiatief. Op basis hiervan kunnen we vier kernmotieven onderscheiden die door deelnemers als belangrijk worden gezien. Deze kernmotieven zijn altruïsme, persoonlijke ontwikkeling, gevraagd worden, en het willen oplossen van een specifiek lokaal probleem.

\section{Gevraagd worden}

Een van de meest genoemde redenen dat mensen zich aansluiten bij burgerinitiatieven is simpelweg dat ze in een bepaald stadium zijn benaderd om bepaalde taken uit te voeren (WRR, 2012; Tonkens e.a., 2015; Hendriks \& Van de Wijdeven, 2014). Dit mechanisme is niet uniek voor burgerinitiatieven: het is ook een van de meest genoemde motieven voor andere vormen van politieke en sociale participatie (Verba e.a., 1995). Gevraagd worden kan worden gezien als een vorm van individueel sociaal belang (Schlozman e.a., 1995). In de meeste gevallen zal mensen worden gevraagd om mee te doen door mensen die al in dezelfde sociale kringen zitten, zoals vrienden, familie, goede kennissen of buren. Het kan dan als individueel sociaal belang worden gezien om geen 'nee' te zeggen, omdat daarmee de relaties binnen deze sociale kring niet onder druk komen te staan, en wellicht zelfs kunnen worden versterkt. Ook belangrijk om op te merken is dat gevraagd worden als motief wordt opgevoerd door participanten in zeer diverse burgerinitiatieven, variërend van een G1000-achtige burgertop (Tonkens e.a., 2015) tot het opzetten van een wijkcentrum (Ham \& Van der Meer, 2015).

\section{Altruïsme}

Een tweede veel genoemd motief om deel te nemen is altruïsme, of een houding gericht op het willen helpen van andere mensen in algemene zin (bijv. Oudijk e.a., 2011; Lammerts \& Verwijs, 2009). Het nastreven van dergelijk maatschappelijk nut kan zowel een individuele als een collectieve vorm aannemen (Lunsing, 2015; Denters, 2016). Bij 'collectief altruïsme' staat de wens centraal om de samenleving of de democratie te versterken, terwijl 'individueel altruïsme' gaat om het vervullen van goed burgerschap. Een participatiesamenleving is van nature gericht op het helpen van anderen, waardoor altruïstische motieven logischerwijs meer aanwezig zouden kunnen zijn. Wel opmerkelijk is dat dergelijke motieven meer worden genoemd in kwantitatieve dan in kwalitatieve studies. De meeste 
studies hanteren een vaste lijst van antwoordcategorieën (onder meer Oudijk e.a., 2011; Lammerts \& Verwijs, 2009), waardoor respondenten al in een bepaalde richting worden gestuurd bij de beantwoording. Dit kan betekenen dat participanten misschien niet uit altruïstische motivatie hebben deelgenomen, maar dat ze, terugkijkend op waarom ze zich ooit hebben aangesloten bij een burgerinitiatief, zich wel sterk identificeren met het willen helpen van andere mensen. Een andere interessante bevinding is dat altruïsme over het algemeen sterker wordt gevoeld door oudere en door gelovige participanten, en dan voornamelijk in het kader van initiatieven die gericht zijn op het helpen van specifieke personen in plaats van een algemener probleem (Fienieg e.a., 2011; Verplanke, 2015).

\section{Persoonlijke ontwikkeling}

Voor jongere participanten lijkt altruïsme minder van belang, en worden motieven die betrekking hebben op persoonlijke ontwikkeling vaker benoemd (Faulk, 2009; Dekker \& De Hart, 2009). Bij dergelijke motieven geldt dat deelnemers een bepaald individueel en materieel belang nastreven (Denters, 2016). Wat voor belang dat precies is, kan verschillen. Sommigen noemen het verhogen van kennis op bepaalde vlakken, zoals kennis van politieke processen of het verbeteren van specifieke vaardigheden (Schlozman e.a., 1995; Lammerts \& Verwijs, 2009). Voor andere participanten is persoonlijke ontwikkeling meer instrumenteel van aard, bijvoorbeeld om de positie op de arbeidsmarkt te verbeteren (Verplanke, 2015) of simpelweg omdat er een vergoeding wordt gegeven om deel te nemen (Tonkens e.a., 2015). Onafhankelijk van de vorm van ontwikkeling of verbetering komen dergelijke motieven voor bij alle soorten initiatieven, van burgertop tot buurttuin. En ook al wordt dit motief meer genoemd door jongere participanten, er is geen steun voor de aanname dat instrumentele motieven de enige drijfveer zijn voor deze doelgroep (Verplanke, 2015: 63).

\section{Specifiek probleem}

Een vierde motief is het willen behalen van collectief materieel gewin, oftewel het willen zorgen voor veranderingen in beleid (Lunsing, 2015; Denters, 2016). In relatie tot burgerinitiatieven, waar de invloed van burgers bij voorkeur niet loopt via beleid, kan dit het beste worden vertaald naar het willen oplossen van een specifiek probleem. Dit motief is sterk verbonden aan wat wel een 'dicht-bij-huislogica' kan worden genoemd (Hurenkamp e.a., 2006): veel participanten willen problemen eigenlijk alleen oplossen als ze in sterke mate door een probleem worden geraakt. De grote variatie in mogelijke problemen betekent dan ook dat dit motief kan voorkomen in initiatieven variërend van zorg (Fienieg e.a., 2011) en burgerwacht (Stokes, 2010) tot de aanleg van een speeltuin (Verplanke, 2015). Vooral in kleinere gemeenten, waar bepaalde diensten door bezuinigingen onder druk komen te staan en in veel gevallen verdwijnen, is te zien dat participanten deelnemen juist om een probleem op te lossen dat door dergelijke bezuinigingen is ontstaan (Ham \& Van der Meer, 2015). Opvallend genoeg zijn participanten in dat soort initiatieven relatief vaak mensen met een hoog wantrouwen jegens de lokale en de landelijke overheid. 


\section{Methoden}

Het empirisch onderzoek voor dit artikel bestond uit het uitzetten van een enquête in de periode van december 2015 tot januari 2016. Deze enquête bestond uit twee onderdelen die door alle respondenten werden ingevuld. Het eerste deel bevatte vragen over de achtergrondkenmerken van respondenten, zoals geslacht, leeftijd en opleidingsniveau. Ook zijn vragen toegevoegd over diverse kenmerken die in onderzoek naar sociale en politieke participatie worden genoemd als belangrijke factoren die participatie kunnen hinderen ofwel verklaren. Een belangrijk voorbeeld van dergelijk onderzoek is het Civic Voluntarism Model (Verba e.a., 1995), dat verschillende factoren benoemt die bepalend kunnen zijn in de mate waarin mensen bereid zijn te participeren in diverse politieke en electorale processen. Belangrijke eigenschappen in dit model, die ook in de enquête voor dit onderzoek zijn opgenomen, zijn de mate waarin mensen zichzelf beschouwen als religieus, en interpersoonlijk vertrouwen. Ook zijn vragen opgenomen over vertrouwen in de lokale en nationale politiek, en over de politieke invloed die respondenten denken te hebben. Verder zijn er vragen gesteld over de mate waarin respondenten zich betrokken voelen bij de buurt waarin zij wonen (Tonkens \& Verhoeven, 2011).

In het tweede deel van het onderzoek kreeg iedere respondent verschillende vignetten te zien. In een vignetstudie krijgen respondenten meerdere korte, hypothetische teksten te zien. Na het lezen van de tekst wordt gevraagd hoe zij op deze hypothetische situatie zouden reageren. Per vignet wordt één fictief burgerinitiatief beschreven en gekoppeld aan een van de vier kernmotieven, zodanig dat uiteindelijk alle combinaties van burgerinitiatieven en kernmotieven aan bod komen.

Voor de vignetten in deze studie zijn drie fictieve burgerinitiatieven gekozen op basis van in Nederland bestaande voorbeelden. Ze variëren allereerst in schaal, dat wil zeggen zowel in het aantal deelnemers dat aan het initiatief zal deelnemen als in de impact die het initiatief heeft. Daarnaast variëren de drie initiatieven in aard, van een nadruk op deliberatie tot een nadruk op het zelf doen. De gekozen burgerinitiatieven staan weergegeven in tabel 1.

Tabel 1 Overzicht van burgerinitiatieven

\begin{tabular}{llll}
\hline Initiatief & Beschrijving & Schaal & Type initiatief \\
\hline Burgertop & $\begin{array}{l}\text { Discussieplatform op wijkniveau, Groot } \\
\text { waarin de belangrijkste proble- } \\
\text { men worden geïdentificeerd en } \\
\text { besproken }\end{array}$ & Deliberatief \\
& $\begin{array}{l}\text { Het omvormen (en bijhouden) } \\
\text { van een leegstaand stuk grond } \\
\text { tot een tuin voor wijkbewoners } \\
\text { Zuurttuin }\end{array}$ & & \\
& $\begin{array}{l}\text { Verlenen van basiszorg aan twee Klein } \\
\text { oudere straatbewoners }\end{array}$ & $\begin{array}{l}\text { Toegepast, met delibe- } \\
\text { rotieve aspecten }\end{array}$ \\
\hline
\end{tabular}


De burgertop is gebaseerd op de G1000 zoals deze is uitgevoerd, onder meer, in Kruiskamp, een wijk in Amersfoort (Michels \& Binnema, 2016). Deze burgertop was een initiatief van burgers, die naar Belgisch voorbeeld een discussieplatform voor wijkbewoners wilden opzetten. Tussen oktober 2014 en januari 2015 kwamen in eerste instantie meer dan honderd, daarna enkele tientallen bewoners samen om op verschillende avonden te discussiëren over problemen in de wijk en manieren om deze problemen op te lossen. Dit initiatief is toegevoegd in ons onderzoek als een deliberatief initiatief, oftewel een initiatief dat voornamelijk draait om het bereiken van consensus over de beste aanpak van de belangrijkste problemen. De burgertop is ook het meest grootschalige burgerinitiatief dat wij in onze vignetten opnemen, aangezien zowel de deelnemers als de besproken onderwerpen uit de gehele wijk komen.

Het initiatief voor een buurttuin is gebaseerd op het project 'Emma's Hof', dat in Den Haag is uitgevoerd. Dit initiatief werd door zes buurtbewoners gestart. Deze mensen zorgden ervoor dat een leegstaand stuk grond midden in een huizenblok kon worden opgekocht, en door bewoners zelf kon worden omgebouwd tot een buurttuin en speelterrein voor buurtbewoners. Het onderhoud van de buurttuin wordt ook nog altijd door omwonenden verzorgd. ${ }^{1}$ Dit initiatief heeft zowel deliberatieve als toegepaste aspecten. In de vignetten is de beschrijving van de buurttuin zo geformuleerd dat respondenten zelf kunnen bepalen wat voor taken zij het liefste zouden uitvoeren. De schaal van dit initiatief is middelgroot en in principe beperkt tot enkele huizenblokken die direct om de tuin zouden liggen.

Als laatste initiatief is gekozen voor een zorginitiatief, waarin buurtbewoners een klein collectief vormen om basiszorg te verlenen aan twee ouderen in de straat. Dit initiatief is wat algemener gevormd naar wat ook wel de sociale agenda van het participatiedenken kan worden genoemd (Verhoeven \& Tonkens, 2013). In dit voorbeeld wordt aan respondenten gevraagd om enkele keren per week redelijk eenvoudige taken te vervullen, zoals koken, boodschappen doen of schoonmaken. Dit zorginitiatief is duidelijk kleinschalig en heeft alleen toegepaste aspecten.

In eerste instantie krijgen alle respondenten een beschrijving van elk initiatief te zien en wordt gevraagd hoe waarschijnlijk het is dat zij aan een dergelijk initiatief zouden deelnemen. Vervolgens worden twaalf vignetten gepresenteerd in een vaste volgorde. In elk vignet wordt een van de initiatieven gekoppeld aan een van de motieven, en is aan respondenten gevraagd in hoeverre zij dat motief zelf een goede reden zouden vinden om deel te nemen aan dat initiatief. Respondenten kunnen een score toekennen van 1 (helemaal geen goede reden) tot 7 (zeer goede reden). Alle vignetten zijn op een vergelijkbare manier geformuleerd als het voorbeeld hieronder, waarin de burgertop als initiatief wordt gekoppeld aan het willen oplossen van een specifiek probleem als kernmotief: 
Tabel 2 Voorbeelden van vignetteksten voor alle motieven

\begin{tabular}{ll}
\hline Motief & Vignettekst \\
\hline $\begin{array}{l}\text { Gevraagd worden (i.c.m. } \\
\text { buurttuin) }\end{array}$ & $\begin{array}{l}\text { Sommige mensen doen mee aan de buurttuin omdat ze door } \\
\text { vrienden, kennissen of buren gevraagd worden om mee te doen. } \\
\text { Zou dit voor u een goede reden zijn om mee te doen aan de } \\
\text { buurttuin? }\end{array}$ \\
Altruïsme (i.c.m. buurttuin) & $\begin{array}{l}\text { Sommige mensen doen mee aan de buurttuin omdat ze graag } \\
\text { andere mensen willen helpen met problemen die zij ervaren, en ze } \\
\text { graag willen bijdragen aan de leefbarheid van de buurt. Zou dit } \\
\text { voor u een goede reden zijn om mee te doen aan de buurttuin? }\end{array}$ \\
Persoonlijke ontwikkeling & $\begin{array}{l}\text { Sommige mensen doen mee aan de zorggroep omdat ze zichzelf } \\
\text { (i.c.m. zorginitiatief) }\end{array}$ \\
$\begin{array}{l}\text { persoonlijk willen ontwikkelen, bijvoorbeeld omdat ze hun CV } \\
\text { kunnen aanvullen door mee te doen. Zou dit voor u een goede } \\
\text { reden zijn om mee te doen aan de zorggroep? }\end{array}$ \\
$\begin{array}{l}\text { Specifiek probleem (i.c.m. } \\
\text { burgertop) }\end{array}$ & $\begin{array}{l}\text { Sommige mensen doen mee aan de burgertop omdat ze een speci- } \\
\text { fiek probleem in hun buurt ervaren, zoals overlast door hangjon- } \\
\text { geren, en dat probleem willen oplossen. Zou dit voor u een goede } \\
\text { reden zijn om deel te nemen aan de burgertop? }\end{array}$ \\
\hline
\end{tabular}

'In uw buurt wordt een burgertop georganiseerd. Het idee van deze burgertop is dat ongeveer 200 mensen uit uw buurt zes keer (één avond per maand) zullen samenkomen, en in groepjes gaan praten over de problemen die in uw buurt spelen.

Het doel van de burgertop is om in overleg te bepalen wat de belangrijkste problemen zijn, maar ook om samen te discussiëren over hoe deze problemen het beste kunnen worden opgelost. Ook politici en ambtenaren uit uw gemeente zullen bij deze avonden aanwezig zijn. Sommige mensen doen mee aan de burgertop omdat ze een specifiek probleem in hun buurt ervaren, zoals overlast door hangjongeren, en dat probleem willen oplossen. Zou dit voor u een goede reden zijn om deel te nemen aan de burgertop?'

Tabel 2 geeft weer hoe de verschillende motieven in de vignetten zijn opgenomen.

In eerste instantie zijn 80 mensen gericht uitgenodigd om deel te nemen aan de enquête. Hierop hebben 39 respondenten $(48,8 \%)$ de enquête daadwerkelijk ingevuld. Vervolgens zijn open uitnodigingen verstuurd via sociale media (wat uiteindelijk 87 respondenten opleverde) en naar studenten van de Executive Master Bestuur en Beleid aan de Universiteit Utrecht (9 respondenten). In totaal hebben dus 135 respondenten de enquête ingevuld. Tabel 3 geeft een overzicht van de karakteristieken van de respondenten.

\section{Resultaten}

We beginnen met het bespreken van de vraag wat voor de respondenten de belangrijkste motieven zijn om deel te nemen aan een burgerinitiatief. Daartoe kijken we naar de gemiddelde scores voor elk motief ten opzichte van elke vorm 
Tabel 3 Overzicht van de karakteristieken van respondenten

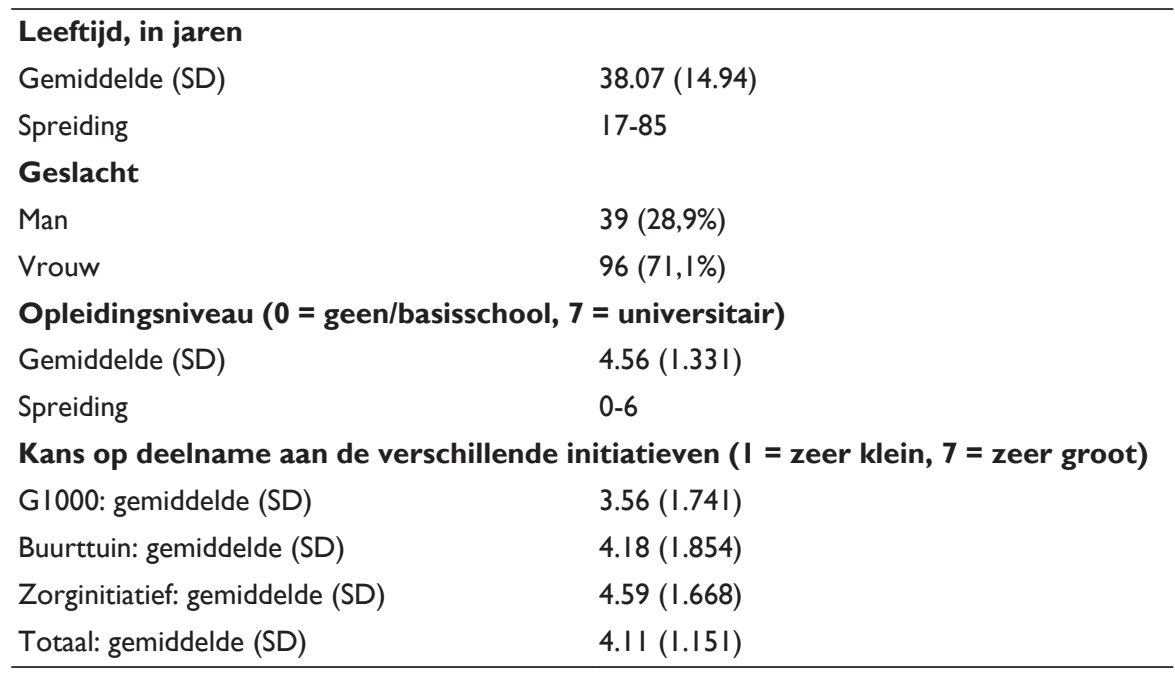

Tabel 4 Gemiddelden en correlatiecoëfficiënten voor motivaties en waarschijnlijkheid van deelname

\begin{tabular}{lllll}
\hline & & Burgertop & Buurttuin & Zorginitiatief \\
\hline Altruïsme & Gemiddelde & 3.85 & 4.42 & 4.64 \\
& Pearson & $.430^{* * *}$ & $.53 I^{* * *}$ & $.464^{* * *}$ \\
& $\mathrm{~N}$ & 108 & 113 & 111 \\
Persoonlijke & Gemiddelde & 3.03 & 3.09 & 3.46 \\
ontwikkeling & Pearson & $.211^{*}$ & $.292^{* *}$ & $.392^{* * *}$ \\
& $\mathrm{~N}$ & 114 & 112 & 113 \\
Specifiek pro- & Gemiddelde & 3.83 & 3.38 & 3.88 \\
bleem & Pearson & $.344^{* * *}$ & $.56 I^{* * *}$ & $.647^{* * *}$ \\
& $\mathrm{~N}$ & 115 & 108 & 113 \\
Gevraagd wor- & Gemiddelde & 3.70 & 4.32 & 4.28 \\
den & Pearson & $.245^{* *}$ & $.48 \mathrm{I}^{* * *}$ & $.519 * * *$ \\
& $\mathrm{~N}$ & 113 & 114 & 110 \\
\hline
\end{tabular}

$* \mathrm{p}<.05 ; * * \mathrm{p}<.01 ; * * * \mathrm{p}<.001$.

van burgerinitiatief. Tabel 4 geeft een overzicht van de gemiddelde waarden en de correlatiecoëfficiënten, die we later zullen bespreken.

Uit de resultaten blijkt allereerst dat respondenten consequent een hoge waardering geven aan altruïstische motieven voor deelname aan burgerinitiatieven. Dit wijst erop dat mensen zich vooral sterk laten motiveren door de wens om anderen te helpen. Dit geldt overigens niet per definitie sterker voor bepaalde 'subtypen' respondenten, zoals meer religieuze mensen; er is geen significant verband tussen 
godsdienstige achtergrond en de sterkte van het altruïstische motief. De enige relevante uitkomst is dat hogere scores op het altruïstische motief samenhangen met een hoge mate van vertrouwen in andere mensen $(r=.419, p<.001){ }^{2}$ Iemand die van nature wantrouwig is, zal dus minder snel geneigd zal zijn om andere mensen, onder wie onbekenden, te helpen.

De dominantie van het altruïstische motief is op zichzelf niet verrassend omdat burgerinitiatieven zich bijna altijd richten op het aanpakken van problemen in de eigen omgeving. Hiermee zijn burgerinitiatieven dus eigenlijk per definitie gericht op het verbeteren van de leefomgeving en het helpen van anderen. Het wekt dan ook geen verbazing dat het altruïstische motief nog sterker is voor de twee kleinere en specifiekere initiatieven, de buurttuin en het zorginitiatief, dan voor het grotere initiatief van de burgertop.

Als we kijken naar wat respondenten als tweede belangrijkste motief noemen om deel te nemen aan een burgerinitiatief, dan zien we opnieuw een tweedeling tussen de burgertop aan de ene kant en de buurttuin en het zorginitiatief aan de andere kant. Voor deelname aan de burgertop wordt het oplossen van een specifiek probleem als tweede belangrijkste motief genoemd, voor deelname aan de kleinere burgerinitiatieven, geldt gevraagd worden als een belangrijk motief. Deze resultaten wijzen erop dat er voor respondenten een duidelijk onderscheid is tussen kleine uitvoerende burgerinitiatieven in de buurt en een groter initiatief dat tot doel heeft plannen te ontwikkelen voor de wijk.

Tot nu toe hebben we gekeken naar de belangrijkste motieven om deel te nemen aan een burgerinitiatief. Maar dit zegt nog niets over de vraag of een sterke aanwezigheid van een bepaald motief ook leidt tot een grotere kans op deelname. Om die vraag te beantwoorden is allereerst aan respondenten de vraag gesteld hoe waarschijnlijk het is dat zij ook daadwerkelijk deelnemen aan elk van de drie burgerinitiatieven. We kijken vervolgens naar de sterkte van het verband tussen enerzijds de score die respondenten geven aan elk motief als een goede reden om deel te nemen aan een bepaald initiatief, en anderzijds de waarschijnlijkheid dat de respondent aan dat initiatief zou deelnemen. De sterkte van het verband wordt gemeten als een Pearson-correlatiecoëfficiënt $(r)$. Hoe hoger de score, des te sterker is het verband. De resultaten van deze analyse zijn ook te vinden in tabel 4.

Altruïsme is wederom een sterk motief; het vertoont voor alle initiatieven een sterke samenhang met de waarschijnlijkheid dat respondenten ook zouden deelnemen aan dat initiatief. Voor de burgertop laat het altruïstische motief van alle motieven zelfs de sterkste samenhang zien met de waarschijnlijkheid van daadwerkelijke deelname. Opvallend is tegelijkertijd dat in vergelijking met de burgertop, voor de twee kleinschalige, meer toegepaste burgerinitiatieven altruïsme een nog sterkere samenhang laat zien met de waarschijnlijkheid van deelname.

2 Ook voor de andere motieven is er geen significant verband met (achtergrond)kenmerken van de respondenten. 
Meer nog dan altruïsme zijn het andere motieven, namelijk het oplossen van een specifiek probleem en, voor het zorginitiatief, gevraagd worden, die een sterke invloed hebben op de uiteindelijke waarschijnlijkheid van deelname aan de twee kleinere voorbeeldinitiatieven. Hier zien we opnieuw hoe een burgertop zich onderscheidt van de andere burgerinitiatieven. Het oplossen van een specifiek probleem en gevraagd worden zijn sterke motieven om daadwerkelijk deel te nemen aan initiatieven in de kleine directe leefomgeving. Voor een burgertop is het effect van het probleemoplossende motief zwakker, waarschijnlijk omdat een burgertop zich niet richt op één specifiek probleem, maar een breed scala aan onderwerpen aan de orde stelt (zie ook Boogaard \& Michels, 2016). Ook gevraagd worden scoort lager bij de burgertop dan bij de andere initiatieven. Niettemin wijzen onderzoeken naar vergelijkbare initiatieven erop dat het aantal deelnemers zonder persoonlijke uitnodigingen een stuk lager zou liggen (bijv. Tonkens e.a., 2015).

Tot slot valt op dat het motief van de persoonlijke ontwikkeling voor alle burgerinitiatieven laag scoort. Niet alleen zien respondenten persoonlijke ontwikkeling als een minder goed motief om deel te nemen, ook de invloed van dit motief op de waarschijnlijkheid om deel te nemen aan elk van de initiatieven is laag. Een analyse van het verband tussen leeftijd en het motief van persoonlijke ontwikkeling wijst uit dat er ook geen bewijs te vinden is voor de theorie dat jongere participanten gevoeliger zouden zijn voor het persoonlijke motief (Hustinx \& Lammertyn, 2003).

Tot besluit kijken we naar mogelijke combinaties van motieven. Eerder onderzoek wijst uit dat deelnemers aan burgerinitiatieven vaak gedreven worden door een combinatie van verschillende motieven, zoals intrinsieke en extrinsieke (Fledderus \& Honingh, 2016), of collectieve en individuele (Van Eijk \& Steen, 2016; Denters, 2016) motieven. Om te zien of ditzelfde ook geldt voor mensen die nog niet deelnemen aan een burgerinitiatief, voeren we een multipele regressieanalyse uit. Bij deze analyse maken de vier kernmotieven deel uit van een model dat de kans op deelname aan de drie burgerinitiatieven zo goed mogelijk kan verklaren. Als combinaties van motieven inderdaad een rol spelen, is dit te zien in de significantie. Motieven die een significante toevoeging aan het model zijn, vormen waarschijnlijk een goede combinatie voor mogelijke deelname aan burgerinitiatieven. De resultaten van de multipele regressieanalyse staan in tabel 5.

De bevindingen laten zien dat combinaties van motieven inderdaad voorkomen bij non-participanten. Bij zowel de burgertop als de buurttuin blijkt de combinatie van altruïsme en het willen oplossen van een specifiek probleem een significant effect te hebben op de waarschijnlijkheid dat iemand zal deelnemen aan deze initiatieven. Voor het zorginitiatief geldt een combinatie van het oplossen van een specifiek probleem en persoonlijke ontwikkeling als een mogelijk motief voor toekomstige deelname. 
Tabel 5 Invloed van combinaties van motieven op waarschijnlijkheid van deelname

\begin{tabular}{llll}
\hline & Burgertop & Buurttuin & Zorginitiatief \\
\hline Altruïsme & $.290(.28 \mathrm{I})^{*}$ & $.277(.240)^{*}$ & $.114(.105)$ \\
Pers. ontwikkeling & $-.010(-.010)$ & $.020(.020)$ & $.154(.17 \mathrm{I})^{*}$ \\
Specifiek probleem & $.260(.240)^{*}$ & $.350(.322)^{* *}$ & $.425(.498)^{* * *}$ \\
Gevraagd worden & $.056(.054)$ & $.198(.164)$ & $.128(.118)$ \\
Constante & $1.231^{*}$ & $1.180^{*}$ & $1.377^{* *}$ \\
$\mathbf{F}$ & $7.606^{* * *}$ & $16.218^{* * *}$ & $25.692^{* * *}$ \\
$\mathbf{R}^{2}$ & .228 & .389 & .497 \\
$\mathbf{N}$ & 108 & 107 & 109 \\
\hline
\end{tabular}

$* \mathrm{p}<.05 ; * * \mathrm{p}<.01 ; * * * \mathrm{p}<.00 \mathrm{I}$. Waarden tussen haakjes zijn gestandaardiseerde bètacoëfficiënten.

De motieven die in combinatie voorkomen, zijn voor de burgertop en de buurttuin niet verrassend: het zijn de motieven die ook afzonderlijk de sterkste samenhang laten zien met de waarschijnlijkheid van deelname (zie tabel 4). Moeilijker te duiden is de combinatie van het oplossen van een specifiek probleem en persoonlijke ontwikkeling bij het zorginitiatief. In de eerdere analyses kwam het motief van persoonlijke ontwikkeling immers consequent als minst belangrijk naar voren. Het laat in ieder geval zien dat bij het zorginitiatief persoonlijke ontwikkeling een motief kan zijn om deel te nemen, maar dan alleen in combinatie met het motief om een concreet probleem aan te pakken.

Tot slot, gevraagd worden is nergens in combinatie met andere motieven significant. Dit duidt erop dat gevraagd worden als motief voor deelname op zichzelf staat: als mensen wordt gevraagd om deel te nemen aan een initiatief, kan dat invloed hebben op de waarschijnlijkheid van deelname zonder dat daar een aanvullend motief voor nodig is.

\section{Conclusie en discussie}

De participatiesamenleving en de doe-democratie gaan ervan uit dat veel publieke taken heel goed door mensen zelf kunnen worden uitgevoerd. Daar is de overheid niet voor nodig. Sterker nog, soms krijgen mensen veel meer zelf voor elkaar dan een overheid ooit zou kunnen. Denk aan allerlei kleinschalige initiatieven die ontstaan in de zorg voor en opvang van mensen met een verstandelijke beperking of met autisme. Begrippen als participatiesamenleving en doe-democratie versluieren dat slechts een beperkte groep mensen initiatieven ontplooit en deelneemt aan deze initiatieven. Veel mensen zijn niet actief. De vraag die wij in dit artikel aan de orde hebben gesteld, is wat deze mensen zou motiveren om actief te worden in burgerinitiatieven. 
Op basis van de literatuur over participatie hebben we vier kernmotieven voor participatie onderscheiden: altruïsme, persoonlijke ontwikkeling, het willen oplossen van een specifiek lokaal probleem en gevraagd worden door een vriend, familielid of goede kennis. Vervolgens hebben we met behulp van vignetten onderzocht wat non-participanten zou motiveren tot deelname aan drie fictieve voorbeeld-burgerinitiatieven: een burgertop, een buurttuin en een zorginitiatief.

Het onderzoek laat zien dat altruïsme als een belangrijk motief wordt genoemd voor deelname aan burgerinitiatieven. Hoewel een hoge score op altruïstische motivatie niet in alle gevallen zal leiden tot een hogere kans op deelname aan een initiatief, is het wel duidelijk dat de respondenten van dit onderzoek zich eerder geneigd voelen tot deelname als dat vanuit een meer algemeen gevoel van hulpvaardigheid is. Dat betekent concreet dat voor het werven van nieuwe participanten juist een beroep zal moeten worden gedaan op de mogelijkheid dergelijke altruïstische motieven te vervullen.

Als de vraag naar motieven gekoppeld wordt aan de waarschijnlijkheid dat men ook zal deelnemen aan een dergelijk initiatief, dan ontstaat een genuanceerder beeld. Voor de twee kleinschalige burgerinitiatieven, de buurttuin en het zorginitiatief, zijn behalve altruïsme ook gevraagd worden en het oplossen van een specifiek probleem belangrijke motieven om mee te doen. Voor de burgertop geldt dit in veel mindere mate. Dit zou ermee te maken kunnen hebben dat een burgertop toch wat verder afstaat van de directe leefwereld van mensen en in die zin ook wat abstracter is.

De bevindingen impliceren dat het moeilijker is om mensen te motiveren om deel te nemen aan een burgertop dan aan een kleinschalig initiatief in de buurt. Een van de meest opvallende uitkomsten is dat gevraagd worden een sterk motief is voor niet-participanten om deel te nemen. Mensen zullen eerder deelnemen wanneer ze gevraagd worden. Voor initiatiefnemers van kleinschalige initiatieven biedt deze uitkomst mogelijkheden om meer mensen te betrekken. Dat vraagt wel om een meer proactieve rol van initiatiefnemers, door bijvoorbeeld zowel binnen als buiten de eigen sociale kring mensen actief te benaderen om mee te doen.

Initiatiefnemers van burgertoppen hebben het moeilijker. Maar het verband dat we signaleren tussen het oplossen van een specifiek probleem en deelname aan een burgerinitiatief biedt wel een interessant aanknopingspunt. Dit verband is voor de burgertop duidelijk lager dan voor de andere initiatieven, wellicht omdat het onderwerp van een burgertop niet erg specifiek is. Tegelijkertijd zien we dat voor zover mensen vanuit een combinatie van motieven deelnemen aan een burgertop, het oplossen van een specifiek probleem daar deel van uitmaakt. Een duidelijk afgebakend onderwerp met een zekere urgentie voor de wijk zou dan ook mogelijk meer mensen kunnen verleiden tot deelname.

De vraag is vervolgens of onze bevindingen ook betekenen dat deelname aan burgerinitiatieven de kwaliteit van de lokale democratie versterkt (Denters \& Boogers, 2016). Onze bevindingen wijzen inderdaad in die richting. Deelname aan 
een burgerinitiatief betekent per definitie al het leveren van een bijdrage aan publiek beleid of een publieke taak. Deelname vanuit altruïstische motieven of om een specifiek probleem op te lossen - beide motieven die een sterk verband laten zien met mogelijke deelname - impliceert bovendien een houding die sterk is gericht op de samenleving en het vervullen van goed burgerschap, en daarmee ook op het versterken van de democratie. Ook mensen die nu nog niet deelnemen aan burgerinitiatieven lijken dus een positieve en constructieve houding te hebben ten aanzien van hun eigen bijdrage aan de lokale democratie.

Maar burgerinitiatieven dragen niet zonder meer bij aan een versterking van de kwaliteit van de lokale democratie. In veel onderzoeken wordt gesteld dat het voor het goed functioneren van burgerinitiatieven belangrijk is dat de overheid faciliteert, maar niet overneemt. Oftewel: ambtenaren moeten burgers de ruimte geven, ze helpen wanneer dat specifiek gevraagd of onontkoombaar is, maar verder een initiatief zo veel mogelijk 'loshouden' (Hendriks \& Van de Wijdeven, 2014). Voor een versterking van de kwaliteit van de lokale democratie is het echter van belang dat overheden soms een actievere rol innemen. Een democratie vereist immers dat voorkomen wordt dat bepaalde groepen worden uitgesloten, dat naar de wensen van alle bewoners wordt geluisterd, dat voorzieningen toegankelijk zijn voor iedereen, en dat de democratische verantwoording goed geregeld is. Insluiting, responsiviteit en toegankelijkheid kunnen onder druk komen wanneer, zoals bij veel burgerinitiatieven het geval is, de actieve burgers onvoldoende representatief zijn voor de bevolking (Peters \& Van Stipdonk, 2016). Dan is het de rol van de overheid om te blijven luisteren naar de wensen van alle burgers, ook naar hen die niet actief zijn, en hier ook naar te handelen. Alleen een actieve en aanvullende rol van de overheid kan bijdragen aan de effectiviteit en legitimiteit van burgerinitiatieven en daarmee van de participatiesamenleving zelf (Verhoeven \& Tonkens, 2011).

Ten slotte nog enkele opmerkingen over de implicaties van de gebruikte onderzoeksmethode. De gebruikte onderzoeksmethode met vignetten wordt nog weinig gebruikt, maar is een goede methode om te onderzoeken welke motieven domineren bij de keuze om deel te nemen aan een burgerinitiatief. De methode kent ook enkele beperkingen. Mogelijk geeft de methode een vertekend beeld van de welwillendheid van non-participanten om deel te nemen aan initiatieven. De respondenten reageren immers op een fictieve situatie. In werkelijkheid kunnen ook andere prioriteiten een rol spelen in de beslissing om wel of niet deel te nemen. Hoewel er bij het opstellen van de enquête is geprobeerd duidelijk aan te geven dat respondenten juist dat soort informatie zouden moeten meenemen in hun beslissing, is het niet uit te sluiten dat de resultaten in zekere mate door deze fictieve aard zijn beïnvloed.

Daarnaast kunnen sociaal wenselijke antwoorden op meerdere manieren de resultaten van dit onderzoek hebben beïnvloed. Het is niet onwaarschijnlijk dat de hoge scores op altruïstische motivaties en, vice versa, de lage scores op persoonlijke ontwikkeling gedeeltelijk zijn veroorzaakt door sociale (on)wenselijkheid. Burgerinitiatieven, zeker als deze (zoals het zorginitiatief) specifiek worden 
benoemd als een manier om anderen te helpen, zijn nou eenmaal een sterk sociaal gericht middel. Hierdoor zullen respondenten wellicht eerder geneigd zijn om altruïstische motieven hoger te waarderen dan persoonlijke motieven. Dat verandert echter weinig aan onze stelling dat altruïsme als motief goed kan worden ingezet om meer mensen bij burgerinitiatieven te betrekken. Zelfs al is deze altruistische houding deels of zelfs volledig ingegeven door sociale wenselijkheid, dan nog betekent dit dat het aanspreken van mensen op een altruïstische houding een betere rekruteringsstrategie is dan de nadruk te leggen op motieven die meer als 'egoïstisch', of in ieder geval als minder sociaal, gezien worden.

We hebben in dit onderzoek, tot slot, vooral gekeken naar motieven om te participeren. Dat betekent dat we geen aandacht hebben besteed aan mogelijke barrières voor participatie. Uit ander onderzoek blijkt bijvoorbeeld dat tijd een belangrijke barrière kan zijn voor participatie (WRR, 2012). Maar tijd is een uitermate subjectief begrip, dat eerder iets zegt over prioriteiten die mensen stellen. Over de manier waarop barrières en motieven zich mogelijkerwijs tot elkaar verhouden, kunnen wij op basis van de door ons uitgevoerde enquête niets zeggen.

\section{Literatuur}

Boogaard, G. \& A.M.B. Michels (eds.), G1000. Ervaring met burgertoppen, Den Haag: 2016.

Boutellier, H., De improvisatiemaatschappij. Over de sociale ordening van een begrensde wereld, Den Haag: 2011.

Dekker, P. \& J. de Hart (eds.), Vrijwilligerswerk in meervoud. Civil Society en vrijwilligerswerk 5, Den Haag: 2009.

Denters, S.A.H., 'Community self-organization: potentials and pitfalls', J. Edelenbos \& I.F. van Meerkerk (eds.), Critical reflections on interactive governance. Self-organization and participation in public governance, Cheltenham: 2016, p. 230-253.

Denters, S.A.H. \& M.J.G.J.A. Boogers, 'Lokale democratie doorgelicht. Inleiding', Bestuurswetenschappen, 2016/4, p. 18-26.

Denters, S.A.H., E. Tonkens, I. Verhoeven \& J.H.M. Bakker, Burgers maken hun buurt, Tilburg: 2013.

Drosterij, G. \& R. Peeters, 'De nieuwe burgerlijkheid. Participatie als conformerende zelfredzaamheid', Beleid en Maatschappij, 2011/4, p. 456-472.

Edelenbos, J., Proces in vorm. Procesbegeleiding van interactieve beleidsvorming over lokale ruimtelijke projecten, Utrecht: 2000.

Eijk, C. van \& T. Steen, 'Why engage in co-production of public services? Mixing theory and empirical evidence', International Review of Administrative Sciences, 2016/1, p. 28-46.

Faulk, L., 'In gesprek met vrijwilligers. Effecten van de levensfase op vrijwillige inzet', P. Dekker \& J. de Hart (eds.), Vrijwilligerswerk in meervoud. Civil Society en vrijwilligerswerk 5, Den Haag: 2009, p. 83-106.

Fienieg, B., V. Nierkens, E. Tonkens, T. Plochg \& K. Stronks, 'Why play an active role? A qualitative examination of lay citizens' main motives for participation in health promotion', Health Promotion International, 2011/3, p. 416-426.

Fledderus, J. \& M.E. Honingh, 'Why people co-produce within activation services. The necessity of motivation and trust', International Review of Administrative Sciences, 2016/1, p. 69-87. 
Graaf, L.J. de, Gedragen beleid. Een bestuurskundig onderzoek naar interactief beleid en draagvlak in de stad Utrecht, Delft: 2007.

Ham, M. \& J. van der Meer, De ondernemende burger. De woelige wereld van lokale initiatieven, Utrecht: 2015.

Hendriks, F. \& T.M.F. van de Wijdeven (eds.), Loshouden en meemaken. Over samenredzaamheid en overheidsparticipatie, Den Haag: 2014.

Hurenkamp, M., E. Tonkens \& J.W. Duyvendak, Wat burgers bezielt. Een onderzoek naar burgerinitiatieven, Amsterdam: 2006.

Hustinx, L. \& F. Lammertyn, 'Collective and reflexive styles of volunteering. A sociological modernization perspective', Voluntas, 2003/2, p. 167-187.

Kisby, B., 'The Big Society. Power to the people?', The Political Quarterly, 2010/4, p. $484-491$.

Lammerts, R. \& R. Verwijs, Deelnemen aan wijkraden. Verwachtingen, motieven en ervaringen van bewoners over participatie in wijkraden, Utrecht: 2009.

Lenos, S., P. Sturm \& R. Vis, Burgerparticipatie in gemeenteland. Quick scan van 34 coalitieakkoorden en raadsprogramma's voor de periode 2006-2010, Amsterdam: 2006.

Lunsing, J.R., De kloof. Effecten van transparant welstandstoezicht, buurtbudgetten en referenda op de door burgers waargenomen afstand tot het bestuur, Den Haag: 2015.

Michels, A.M.B. \& H. Binnema, 'Hoe divers, invloedrijk en deliberatief is een G1000? Het ontwerp van een burgertop en de verwezenlijking van democratische waarden', Bestuurswetenschappen, 2016/1, p. 17-36.

Oudijk, D., I. Woittiez \& A. de Boer, 'More family responsibility, more informal care? The effect of motivation on the giving of informal care by people aged over 50 in the Netherlands compared to other European countries', Health Policy, 2011/3, p. 228-235.

Peters, K. \& V.P. van Stipdonk, 'Hoe staat de lokale democratie in Nederland er voor?', Bestuurswetenschappen, 2016/4, p. 27-49.

Pröpper, I.M.A.M., De aanpak van interactief beleid. Elke situatie is anders, Bussum: 2009.

Raad voor het openbaar bestuur (Rob), Burgers betrokken, betrokken burgers, Den Haag: 2004.

Raad voor het openbaar bestuur (Rob), Loslaten in vertrouwen. Naar een nieuwe verhouding tussen overheid, markt én samenleving, Den Haag: 2012.

Schlozman, K.L., S. Verba \& H.E. Brady, 'Participation's not a paradox: the view from American activists', British Journal of Political Science, 1995/1, p. 1-36.

Stokes, R., Betrokken burgers. Motieven, verwachtingen en ervaringen van burgers en politie in burgerparticipatieprojecten, Enschede: 2010.

Tonkens, E. \& I. Verhoeven, Bewonersinitiatieven. Proeftuin voor partnerschap tussen burgers en overheid, Amsterdam: 2011.

Tonkens, E., M.J. Trappenburg, M. Hurenkamp \& J. Schmidt, Montessori-democratie. Spanningen tussen burgerparticipatie en de lokale politiek, Amsterdam: 2015.

Verba, S., K.L. Schlozman \& H.E. Brady, Voice and equality. Civic voluntarism in American politics, Harvard: 1995.

Verhoeven, I. \& E. Tonkens, 'Bewonersinitiatieven. Partnerschap tussen burgers en overheid', Beleid en Maatschappij, 2011/4, p. 419-437.

Verhoeven, I. \& E. Tonkens, 'Talking active citizenship. Framing welfare state reform in England and the Netherlands', Social Policy and Society, 2013/3, p. 415-426.

Verplanke, L., 'Gratis maar niet voor niets. Motieven van vrijwilligers in zorg en welzijn', M. van Bochove, E. Tonkens \& L. Verplanke (eds.), Kunnen we dat (niet) aan vrijwilligers overlaten? Nieuwe verhoudingen tussen vrijwilligers en professionals in zorg en welzijn, Den Haag: 2015, p. 47-64. 
Gideon Broekhuizen \& Ank Michels

Wetenschappelijke Raad voor het Regeringsbeleid (WRR), Vertrouwen in burgers, Amsterdam: 2012.

Wijdeven, T.M.F. van de, Doe-democratie. Over actief burgerschap in stadswijken, Delft: 2012. 